\title{
Da tela à vitrine - reincidências no romance brasileiro contemporâneo
}

\author{
Renata Farias de Felippe \\ UFSM \\ Anselmo Peres Alós \\ UFSM
}

\begin{abstract}
Resumo
A partir do conceito de prosa de vitrine - utilizado por Flora Süssekind para definir a literatura recente voltada para o registro ao avesso da espetacularização da sociedade - e do romance O dia Mastroianni (2007), de João Paulo Cuenca, este trabalho pretende delinear as peculiaridades de um "modo de ler" contemporâneo, que associa o sentido e as imagens literárias aos referenciais oriundos de diferentes linguagens. Sensível às especificidades desse modo de ler, a literatura de vitrine parece assegurar o seu espaço e contribuir para a permanência do literário (a despeito das muitas formas de fabulação), estratégia que revela uma espécie peculiar de engajamento.

Palavras-chave: prosa de vitrine; romance brasileiro contemporâneo; engajamentos.

Abstract

Departing from the concept of shopwindow prose by Flora Süssekind to characterize the recent literature focused on the inside out record of the spectacle phenomenon in society, and the novel O Dia Mastroianni (2007), by João Paulo Cuenca, this essay aims to outline the peculiarities of a contemporary "way of reading" that associates meaning and literary images to referential sources from diverse languages. Aware of the specificities of this way of reading, the shopwindow literature seems to ensure its space and contribute to literary permanence (despite the many forms of confabulation), a strategy that reveals a peculiar kind of engagement.
\end{abstract}

Keywords: shopwindow prose; contemporary Brazilian novel; engagement. 
1. Expressão utilizada por Derrida para definir a relação entre os gêneros na obra de Heléne Cixous. Cf. DERRIDA, 2005, p. 22-23.

\section{Cf. VILLAÇA, Nízia.}

Mixologias, 2010, p. 42.

3. Flora Süssekind, ao tratar sobre a literatura brasileira do final do século passado no ensaio "Ficção 80: dobradiças e vitrines", contraria a visão "apocalíptica" do historiador Georges Duby, para quem o romance estaria em vias de desaparecer. Segundo Duby, a contemporaneidade assistiria ao retorno do ensaio. Para Süssekind, porém, "tanto a linguagem crítica tem se encaminhado para uma dicção mais ensaística, quanto a prosa de ficção tem se deixado contaminar pelo aspecto reflexivo, pela capacidade de se pôr à prova, do ensaio". Cf. SÜSSEKIND, Flora. Papéis colados, 2003, p. 265.

4. A espetacularização do ego possibilitada pelas redes sociais, por outro lado, leva-nos a questionar o que há de "autoral" e/ou de subserviente nessa autoexposição.

5. Cf. BARTHES, Roland. O rumor da língua, 1988, p. 12.
Desde o surgimento da arte cinematográfica, a relação entre o cinema e a literatura tem sido estreita e, diríamos até, profícua, já que aberta à possibilidade de estabelecimento de uma hospitalidade generosa ${ }^{1}$. A mútua influência entre as expressões, as possibilidades criativas por ela engendradas e a formação do imaginário comum são problemáticas que por ora nos interessam. Antes mesmo de pensarmos o elo literatura e cinema, é impossível ignorar o fato de o universo literário ter sido sensível a outros suportes tecnológicos em diversas épocas, como por exemplo, ao telégrafo, na era futurista. Outro fator que atesta a confluência intermídias pode ser observado mais recentemente, quando a televisão e o videoclipe levaram a fiç̧ão a uma tendência minimalista, e à literatura sobre periferia, seja ela com on sem cunbo documentário ${ }^{2}$. O incessante e inevitável contágio entre mídias e expressões, não significa, necessariamente, o atestado de óbito da cultura escrita, de acordo com Roland Barthes. Ainda que os elementos constituintes da memória e do imaginário comuns hoje provenham da cultura visual/digital, a escrita parece insubstituível, em termos de (res)significação imagética.

Com relação à longevidade da literatura, esta parece assegurada tanto por sua faceta fundadora quanto pela capacidade de incorporar a agilidade e a concisão que caracterizam outros meios. Os paradoxos e/ou as incertezas que regem a contemporaneidade, onipresentes nas manifestações artísticas e culturais recentes, encontram na literatura um espaço, em certo sentido, mais afeito à reflexão e à crítica, se considerarmos, por exemplo, a crescente tendência ensaística da narrativa literária ${ }^{3}$, desenvolvida por autores já canônicos como Jorge Luis Borges e Julio Cortázar àqueles mais recentes, como Sérgio Sant'anna, Silviano Santiago e, mais recentemente ainda, João Paulo Cuenca. Se a literatura atual se mostra um campo propício à (auto)reflexividade - tanto relativa à própria escritura quanto voltada à problemática do próprio sujeito enquanto escritor -, ela se mostra uma ferramenta ainda relevante em um período marcado pela irrupção de individualidades cindidas, contingentes e mutáveis, traços que, por sua vez, podem ser vistos como efeitos da incessante interpelação midiática sobre o sujeito contemporâneo, tornado (compulsoriamente) receptor/espectador 4 .

A despeito do senso comum, que associa a profusão de imagens à agonia do texto escrito, Roland Barthes - em $O$ rumor da lingua (1984) - defende a hegemonia da cultura escrita sobre a visual, ao afirmar que "nós somos, muito mais do que outrora e a despeito da invasão das imagens, uma civilização da escrita", pois o "sentido só existe quando denominado, e o mundo dos significados não é outro senão o da linguagem" com tal perspectiva, o "valor" das imagens - cinematográficas ou não - não estaria nelas mesmas, mas seria, de certo modo, mensurável a partir dos discursos que originam. Elementos que 
desencadeiam a máquina da escrita, as imagens estariam sujeitas à leitura, processo primeiro no desenrolar da cadeia dos desejos (desejo de leitura, desejo de palavra, desejo de imagem, desejo de saber). Ainda segundo R. Barthes:

[...] na leitura todas as emoções do corpo estão presentes, misturadas, enroladas: a fascinação, a vagância, a dor, a volúpia; a leitura produz um corpo transtornado. [...] a leitura é condutora do Desejo de escrever. [...] e a cadeia dos desejos começa a desenrolar-se, cada leitura valendo pela escritura que gera, até o infinito ${ }^{6}$.

A partir dos pressupostos barthesianos, pode-se inferir que o que a leitura desejante reivindica não é a escrita, mero produto de um vazio, simultaneamente, incontornável e criador ${ }^{7}$, mas o texto primeiro, disponível à codificação parcial, ou ainda, ocasional, jamais à entrega absoluta. Escrever sobre (um romance, um filme), não deixa de ser um ato de apropriação - e de certa forma, de traição - do texto primeiro.

O cinema - responsável pela formulação de uma memória que, como afirma Ricardo Piglia, não é mais a de Shakespeare - é um importante dinamizador de uma espécie de máquina da escrita ${ }^{8}$. Além de fornecer material para a crítica cinematográfica, o cinema oferece à literatura contemporânea referências formais e temáticas, além de contribuir para o surgimento de uma literatura ágil, que apela para a nossa memória espectatorial.

Para o crítico argentino Ricardo Piglia, o cinema seria responsável pelo estabelecimento de uma memória cujos referenciais "aparecem frequentemente sob a forma degradada da cultura de massas" . O repertório do sujeito moderno - desde o surgimento dos folhetins, passando pela experiência cinematográfica e televisiva, até a realidade virtual - é construído em grande parte pelas formas estereotipadas da cultura popular. A memória coletiva, longe de ser a memória de Shakeaspeare, seria moldada pelos filmes de Hollywood, processo que, segundo Piglia, seria materializado com maestria pelos romances de Manuel Puig ${ }^{10}$.

O cinema como inspiração e/ou argumento literário é uma possibilidade materializada pela publicação de roteiros literários, o que nos leva a interrogar se presenciamos a emergência de um gênero. Os roteiros destinados à publicação são modificados para atender a uma nova função (a de leitura), processo que materializa o retorno à palavra e que vai ao encontro das premissas de Roland Barthes anteriormente referidas. Viridiana (1960), de Luís Buñuel, por exemplo, está entre os clássicos do cinema cujo roteiro foi publicado na Espanha, o que ocorreu com alguns dos roteiros de Pedro Almodóvar (Hable com ella; La mala educación, Volver). No Brasil, a coleção Aplauso, da Imprensa Oficial do Estado de São Paulo, publicou, entre outros,
6. Ibidem, p. 49-50.

7. Entendemos o "desejo" como um vazio, como uma potência que, insatisfeita, está sujeita ao eterno retorno. Esse "eterno retorno", porém, faz-se na diferença.

8. A literatura também dinamiza a máquina cinematográfica, principalmente, por lhe oferecer uma infinidade de argumentos fílmicos - como no caso das adaptações -, temas e referências. Praticamente toda a filmografia de Stanley Kubrick, por exemplo, foi inspirada em romances, sejam eles consagrados - Lolita (1955), de Wladmir Nabokov e Traumnovelle (1926), de Arthur Schnitzler inspiraram os filmes Lolita (1962) e Eyeswideshut (1999) - ou que assim se tornaram - Redalert (1958), de Peter George, inspirou o filme Dr. Strangelove (1964). No caso de Redalert, a adaptação de Kubrick parece "reabilitar" o romance, revesti-lo de uma outra (ou de alguma) aura.

9. Ainda que críticos como Massimo Canevacci questionem hoje o sentido da expressão "cultura de massas", mantivemos a citação, conforme o texto original.

10. Cf. PIGLIA, Ricardo.

"O escritor enquanto crítico". Revista Travessia: a estética do fragmento, n. 33, 1996, p. 53. 
11. O espectador como "refém" das imagens é um dos preceitos $\mathrm{da}$ teoria do dispositivo e um pressuposto partilhado por críticos como Jean-Paul Sartre, Guy Debord e Louis Althusser. Criticada por seu teor oculofóbico, a teoria do dispositivo tem sido confrontada pela teoria da espectatoralidade, que vê no receptor um sujeito discursivo. Cf. STAM, Robert. Introdução à teoria do cinema, 2003, p. 347. Robert Stam, ao tratar sobre as posições espectatoriais, vale-se de argumentos que podem ser redirecionados para pensarmos a posição do leitor na contemporaneidade: "As posições espectatoriais são multiformes, fissuradas, esquizofrênicas, desigualmente desenvolvidas, descontínuas dos pontos de vista discursivo e político, formando parte de um território mutante de diferenças e contradições que se ramificam”. Ibidem, p. 259.

12. CANEVACCI, Massimo. $A$ antropologia da comunicação visual, 2001, p. 239. o roteiro de $A$ cartomante (2004), escrito por Wagner de Assis e inspirado, por sua vez, no conto de Machado de Assis. Eu sei que vou te amar (1986), filme escrito e dirigido por Arnaldo Jabor, foi transformado em romance pelo próprio Jabor em 2006. Em uma outra direção, as pesquisas realizadas por Tata Amaral para a concepção da série para a TV e do filme Antônia (2006) ultrapassaram a demanda fílmica e originaram o livro de contos Hollywood depois do terreno baldio (2007). Diante do fato, é possível refuncionalizarmos a perspectiva de Ricardo Piglia: se os filmes de Hollywood nos legaram uma memória, como o próprio título do livro de Amaral expressa, no nível da experiência o processo de concepção cinematográfica pode oportunizar uma abertura à criação literária.

Todas as manifestações exemplificam a relação de hospitalidade generosa, mutuamente produtiva, que atravessa a relação literatura e cinema. O cruzamento entre diferentes expressões parece tão inevitável quanto necessário. Se considerarmos a (re) construção do olhar após a experiência cinematográfica e a sobrecarga de estímulos visuais que nos interpelam desde o século passado, a literatura não poderia ficar imune a tantos apelos. A existência do literário está ligada a do próprio leitor, cujo olhar, imaginário e mesmo disponível foram profundamente afetados pelo ritmo acelerado das mutações sócio-político-econômicas, pela velocidade da informação e pela hegemonia da cultura visual (também mais "rápida”, em termos de recepção). O fato de o receptor (seja ele espectador ou leitor) estar sujeito a tantos estímulos visuais e informações, porém, não significa que ele seja mero produto de cooptação ${ }^{11}$, já que ele escolhe o meio que melhor atende às suas expectativas e demandas. Canevacci, ao tratar sobre a influência da cultura de consumo na formação do imaginário e do repertório contemporâneos, revela que

[a] cultura do consumo é fundada na constante produção e reprodução de sinais bem reconhecíveis por seus donos e por seu público; ela não encoraja um conformismo passivo na escolha das mercadorias, mas, pelo contrário, procura educar os individuos a ler as diferenças dos sinais, a decodificar facilmente as infinitas minúcias que diferenciam as roupas, os livros, os alimentos, os automóveis, o ambiente. Dessa forma, as distinções de classe e dos diversos segmentos de classe, e ainda as subculturas, ao invés de diluir-se, se fortalecem e se complicam: novos minissímbolos precisam ser descobertos para manter as diferenças ${ }^{12}$.

No caso específico do leitor contemporâneo, ele pode ter se tornado, em certo sentido, mais "exigente"; mais afeito à descrição sucinta, às elipses narrativas e à ambiguidade, o leitor parece esboçar uma espécie de autoria, já que cabe a ele o "preenchimento" diegético e semântico de narrativas fragmentadas e, por vezes, caóticas. 
Voltada para um leitor cindido e portador de múltiplos referenciais - o próprio escritor, enquanto sujeito contemporâneo, é também objeto de incontáveis interpelações -, a literatura contemporânea parece ciente do desafio de conquistar e/ou manter o seu público entre tantos meios e estímulos. No ensaio "Ficção 80", ao tratar sobre os inúmeros influxos que interpelam e afetam o literário, Flora Süssekind, revela uma recorrência: o fato de a ficção recente apresentar-se como metamídia, estratégia que funciona como um "registro ao avesso da espetacularização da sociedade brasileira”, ocorrida a partir da década de $70^{13}$. Süssekind define as manifestações que seguem tal tendência como prosa de vitrine, na qual são expostas e observadas "personagens sem fundo, sem privacidade, quase imagens de vídeo num texto espelhado onde se cruzam, fragmentárias, velozes, outras imagens, outros pedaços de prosa igualmente anônimos, igualmente pela metade" ${ }^{14}$. Segundo a autora, entre o leitor e uma tendência específica da literatura brasileira pós-moderna - praticada por autores como Valêncio Xavier e João Gilberto Noll - há uma transparência irônica, uma parede de vidro.

Ora trechos de filmes, outdoors, notícias de jornal, ora o rádio, a tv, a publicidade, figuras da mídia que se cruzam com os personagens anônimos de uma ficção que, [...], se transforma numa metamídia, registro ao avesso da espetacularização da sociedade brasileira nas duas últimas décadas; [...]. Seja no sentido de duplicar as instâncias narrativas, ora subjetivas, ora anônimas; seja na reavaliação tanto da ideia de privacidade, do narrar como revelação da própria experiência vital, convertidos em impossibilidades; quanto das imagens urbanas correntes, que se exibem mas são vistas de fora, [...]. Com uma parede de vidro no meio ${ }^{15}$.

À semelhança do espectador, o leitor de hoje tem, necessariamente, uma perspectiva cindida e "contaminada" por inúmeros influxos, o que acaba por exigir desenvoltura do escritor - que, enquanto sujeito contemporâneo, é também objeto de interpelação midiática e "leitor" de múltiplos estímulos - no que diz respeito à orquestração de tantas vozes. Seria a capacidade de articular múltiplos discursos uma nova "literariedade", quando pensamos as manifestações literárias recentes? A questão, necessariamente retórica, provavelmente seja também irrelevante, quando pensamos o objeto literário hodierno exatamente como um espaço de inespecificidades.

Se a problemática da linguagem é um lugar comum na literatura denominada pós-moderna - traço cuja reiteração nos parece inevitável dadas as circunstâncias de recepção e de circulação dos bens culturais e artísticos - essa presença é, frequentemente, uma estratégia autoirônica e mesmo metairônica ${ }^{16}$, como
13. SÜSSEKIND, Flora. Papéis colados, 2003, p. 258.

14. Ibidem, p. 258.

15. Ibidem, p. 258.

16. Característica entendida "como uma crítica que se torna criação e que se afirma, portanto, em um processo de revisão crítica da linguagem". BUSATO, Susana. "A consciência do zero como a lógica da razão antropofágica da poesia brasileira contemporânea", 2010, p. 16. 
17. Beatriz Resende, ao destacar a multiplicidade da literatura contemporânea, menciona autores cujos nomes irrompem na década de 90 (como Adriana Lisboa e Luiz Ruffato) e na primeira década deste século (entre eles, Joca Reiners Terron e João Paulo Cuenca). Ainda que tais escritores apresentem marcas autorais específicas, Resende sublinha um ponto comum: o fato de os escritores recentes produzerem "libertos de qualquer necessidade de denúncias (anos 70 e 80) ou exaltação do nacional reapropriado (anos 80)". A maioria dos textos desses escritores seria marcada pela necessidade de manifestar a urgência, ou ainda, por uma presentificação radical, obsessão "que contrasta com um momento anterior, de valorização da história e do passado, quer pela força com que vigeu o romance histórico, quer por manifestações de ufanismo em relação a momentos de construção da identidade nacional". Para maiores detalhes, ver: RESENDE, Beatriz. Contemporâneos, 2008, p. 23-24.

18. O trânsito por outros meios resulta, eventualmente, na construção da imagem do escritor performer, persona cuja travessia multimidiática resulta em uma consagração que dispensa o reconhecimento acadêmico. É o caso, por exemplo, de Lourenço Mutarelli, escritor oriundo do universo das HQs, romancista, roteirista e que encarnou um de seus próprios personagens no filme O Natimorto (2009). podemos observar no romace $O$ dia Mastroianni (2007), de João Paulo Cuenca ${ }^{17}$.

Assim como muitos de seus contemporâneos, Cuenca é um autor cuja atuação se estende por gêneros e meios variados: sua produção passa, por exemplo, pelo gênero crônica - jornal O Globo (2006-2010) e revista TPM (2004-2006) - e pelo roteiro televisivo - Afinal, o que querem as mulheres? (2011), série exibida pela rede Globo ${ }^{18}$. Mais do que exercer uma influência direta sobre a criação literária, a atuação multimidiática do escritor engendra também funções de leitura. No caso específico do romance O dia Mastroianni (2007), a capa da primeira edição do livro, uma espécie de colagem simulacrada de cartazes de filmes antigos, explicita a profusão e o mútuo contágio entre mídias, o que é reforçado pelo título da narrativa, no qual o sobrenome do ator italiano é utilizado como adjetivo.

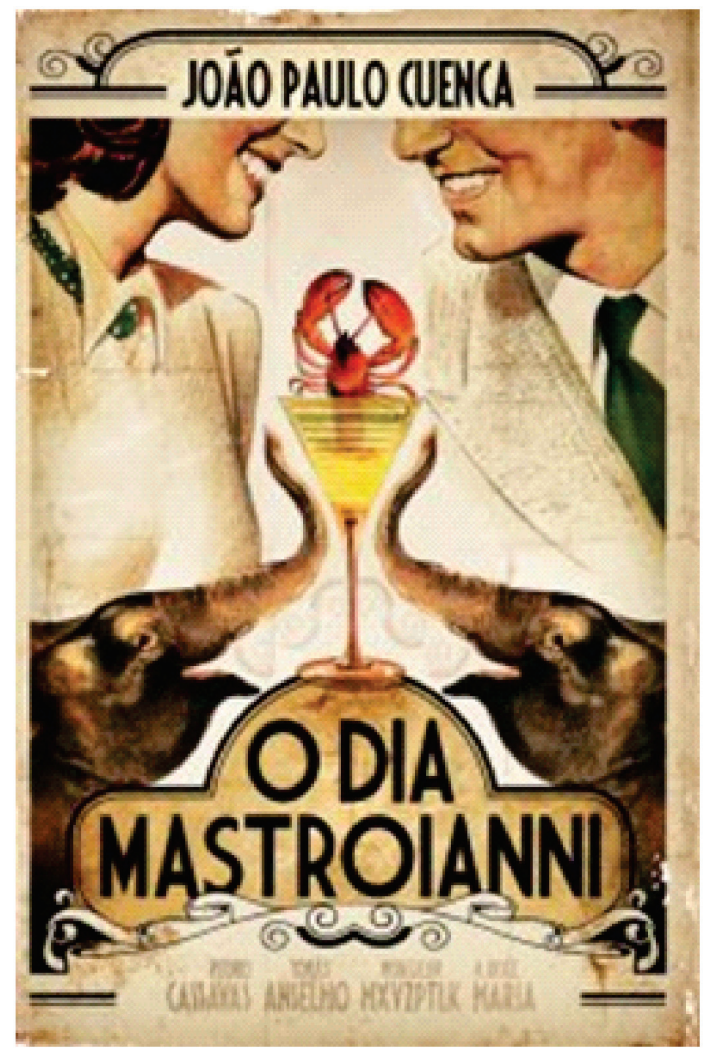

Fig. 01. Capa da primeira ediçáo (2007)

Se a problemática da linguagem é um lugar comum no romance denominado pós-moderno, na narrativa em análise o vazio surge como um local de circunscrição. Nele, o vaz̧io da linguagem, parece espelhar o vazio da própria literatura, que esvaziada de toda a "utilidade" (seja lúdica, quando confrontada com as possibilidades de entretenimento oferecidas por outros meios; seja enquanto modo de mobilização político-social), não consegue sair de si mesma. No romance, várias são as passagens 
que tratam sobre o esvaziamento dos projetos geracionais e, por extensão, dos literários, como é possível observar a seguir:

Aos dândis precoces, escritores sem livros, músicos sem discos, cineastas sem filmes com quem conversávamos por citações de romances inexistentes, flanando sob pontes e mesas e botecos como pândegos muito sólidos, lordes sem um tostão nos bolsos, trocando os dias pelas noites e as noites por coisa alguma! Bebamos à nossa perpétua disponibilidade para vernissages inúteis, bocas-livres sem convite! Brindemos ao nosso futuro e passado, a enredar fiapos de vida dedicados ao culto do ócio, de nós mesmos e de paixões viróticas: nossa doce e irreparável adolescência. [grifos nossos]. ${ }^{19}$

Nas passagens em destaque, a incompletude, a improdutividade ("escritores sem livros, músicos sem discos, trocando os dias pelas noites e as noites por coisa nenhuma") e o narcisismo geracional ("a enredar fiapos de vida dedicados ao culto do ócio, de nós mesmos") são assinalados. O próprio dandismo - cujo refinamento e afetação soam incompatíveis com os nossos tempo e lugar -, associado à ideia de precocidade geracional, direciona para um anacronismo irônico. Por outro lado, o culto ao estilo, característico ao dandismo, é um aspecto que o aproxima da literatura dita pós-moderna.

O mencionado anacronismo irônico deriva, no romance, do intento superficial e deslocado de seu protagonista. Pedro Cassavas, personagem principal da narrativa, e seu amigo Tomás Anselmo - jovens de classe média, na faixa dos vinte anos - são movidos pela pretensão de repetir la dolce vita do personagem interpretado por Marcelo Mastroianni no filme de Fellini. O ridículo da situação já aparece no início da narrativa, quando a dupla tenta reproduzir a trajetória do personagem icônico em um espaço urbano caótico e degradado. Apesar de não nomeada, a cidade onde os fatos ocorrem parece, a princípio, uma capital brasileira, na qual perambulam menores abandonados, mendigos, um traficante disfarçado de vendedor de churros. Ao longo da narrativa, no entanto, os personagens parecem transitar por uma grande cidade qualquer, ou melhor: por uma metrópole simulacrada ${ }^{20}$. Em comum com o protagonista de La dolce vita, Cassavas e Anselmo são personagens, em certo sentido, "rasas", entediadas e hedonistas. Ao contrário de Marcello, o jornalista que protagoniza o filme, o itinerário dos personagens de Cuenca é despido do glamour decadente da Roma sessentista: há no romance, inclusive, passagens pela escatologia. Outra diferença entre o personagem interpretado por Mastroianni e a dupla está na postura autorreflexiva e autoirônica adotada pelo protagonista e narrador (predominante) do romance. Ao tratar sobre si próprio, Cassavas destaca, por exemplo, a sua aparência infantil e a sua própria inconstância, a qual o impede de concretizar qualquer meta.
19. CUENCA, João Paulo. O dia Mastroianni, 2007, p. 23.

20. Fabiano Viana Oliveira reapropria-se do ideário de Baudrillard para conceituar o simulacro como "todo o tipo de estereótipo, de modelo, cujo significado funciona por si só, sem a necessidade de um referente físico ou factual. São signos ou imagens com sentidos próprios, produzindo realidades autônomas além da realidade de fato". Cf. OLIVEIRA, Fabiano. "Conhecendo o simulacro". Caligrama, 2005, s/p. 
21. CUENCA, João Paulo. O dia Mastroianni, 2007, p. 31.

22. Ibidem, p. 49-50.

23. Ibidem, p. 23-24.
Ao final, encaro meu retrato infantil na parede enquanto Péricles seca o meu rosto: contraio os maxilares, já sem constrangimento em me sentir perigosamente cruel, com um gosto salgado de destruição nos lábios, uma bomba de nêutrons embaixo do braço capaz de botar alguns prédios e calcinhas abaixo! ${ }^{21}$ [grifos nossos].

Cruzo as pernas sobre uma chaiselongue e assisto a tudo com um sorriso no rosto. Penso em acender um charuto e fumar ali mesmo, mas lembro que não fumo tabaco. Aperto os olhos e faço um "L" com o dedão e o indicador na frente do rosto, iniciando o estudo de um plano de câmera que nunca irá existir. [...].

Mas a verdade é que não ambiciono nada.

("a diplomacia como diplomata!")

Não estou me preparando para nada.

(“o subsídio governamental em Paris!”)

E não conheço o prazer de um plano realizado. [grifos nossos]. ${ }^{22}$

$\mathrm{Na}$ última frase em itálico, ao associar um plano realizado ao prazer, o narrador-personagem assume a própria inutilidade e também a insatisfação diante da ausência de concretizações. O substantivo "plano", utilizado como sinônimo tanto de plano cinematográfico quanto de "projeto" é também uma dupla irrealização. A situação do personagem parece expressar, metonimicamente, as angústias da geração 00 que, alheia às urgências político-sociais e coletivas, enfrentaria "exílios" e "guerras" movidos por anseios individuais, problemas distintos daqueles enfrentados pelas gerações que lhe antecederam:

Muitos tentaram a vida fora, exilando-se num exterior mitológico, dedicando-se à vera arte de lavar pratos ou trabalhar de babá, limpando com diplomas universitários de ciências humanas os perfumados restos de criancinhas caucasoides de boa estirpe. A desistência do país, no início vista com inveja e deslumbre por todos, sempre era premiada por algum evento incerto que os obrigava a voltar: falta de dinheiro, acessos de pânico, envolvimento em pequenos crimes, mortes na família, ou, ainda, tornados e enchentes que destruiam as metrópoles de vidro para onde migravam -como se houvesse uma força misteriosa que os atraísse de volta à cidade perdida de si mesma, aos bares, às mesas e às cadeiras de todo mundo e de ninguém, aos copos e aos cardápios mordidos de sempre. Desembarcavam cabisbaixos, veteranos de uma guerra perdida.

A única guerra que poderiam algum dia combater. [grifos nossos]. ${ }^{23}$

Os "veteranos" dessa "guerra pós-moderna" inevitavelmente fracassam: voltados para si próprios, para a descoberta de novidades e de prazeres, não conseguem decifrar e tampouco driblar as urgências e as incertezas da existência empírica. Solitário e cindido, o sujeito pós-moderno é insignificante, impotente diante das assustadoras metrópoles de vidro, na qual não estabelece laços duradouros nem esboça planos coletivos, já que 
a empatia é uma impossibilidade. Em conversa com uma de suas (quase) conquistas - a personagem Verônica -, por exemplo, Cassavas não só assinala a indiferença de sua interlocutora como prossegue com a sua "tergiversação". A passagem ilustra a mútua ausência de empatia, a impossibilidade de estabelecimento de um verdadeiro diálogo entre os personagens:

- [...]. Vivemos sem registro algum! Sequer temos a ilusão da permanência, Verônica - digo em tom grave, epifânico, enquanto a menina verte espirais de indiferença pelas bochechas. O videotape daria a nós a certeza de que continuamos existindo! Eu e você, sob as luzes brancas do bingo . [grifos nossos] $]^{24}$.

No fragmento, não por acaso, a imagem na tela de vidro aparece como a única possibilidade de permanência, como um modo de burlar a fugacidade das relações, das ideias, que hoje parecem seguir o ritmo frenético da informação. Além da passagem, vários são os fragmentos do romance que exemplificam a prosa de vitrine, definida por Süssekind, como o destacado a seguir: "Escreveria platitudes: Vivo uma ilusão ficcional que não é somente autobiográfica, mas cinematográfica: conto a vida a mim mesmo (o bar, a barbearia, essa boutique) e vivo a vida que estou contando, $e$ vejo em 16:9 o que estou vivendo'.' 25 [grifos nossos]. No fragmento, a referência explícita à cultura visual - e, no caso da menção à tela 16:9, a referência pode também ser associada à cultura digital - está ligada aos elementos da literatura denominada pós-moderna, especialmente, o traço autorreflexivo e (ficcionalmente) autobiográfico $^{26}$. No entanto, na passagem, o lugar comum da autorreflexão adquire a faceta metamidiática e, em certo sentido, metacrítica: o narrador não apenas revela que viver é também (auto)ficcionalizar-se - "vivo uma ilusão ficcional/vivo a vida que estou contando" -, como também admite que o processo envolve, necessariamente, diversas mídias ("vejo em 16:9 o que estou vivendo"). Os meios que nos interpelam fazem, de alguma forma, parte não apenas do sujeito social mas do sujeito enquanto artista, diretor, escritor. Se na passagem encontramos mais uma constatação - a hegemonia da cultura visual e a ênfase no eu cindido - do que uma crítica, o diálogo entre o protagonista e uma voz que se expressa em caixa alta é contundentemente crítico. Essa voz parece assumir múltiplas perspectivas: ora a do leitor, ora a do crítico, ora a do personagem (em diálogo consigo), ora a do escritor (não o sujeito empírico, mas aquele tornado personagem ao assumir a voz em questão). No fragmento a seguir, por exemplo, é possível entrever a interlocução personagem-escritor, ou ainda, personagem-leitor:

- VOCÊ TEM MEDO DE MORRER?

- Não tenho medo de nada. A morte é nada além do que um relógio sem o ponteiro das horas!
24. Ibidem, p. 121.

25. Ibidem, p. 49.

26. O livro Escritas de si, escritas do outro (2012), de Diana Klinger, é uma detalhada reflexão que trata sobre a reincidência autoficcional na literatura brasileira e latinoamericana atuais. 
27. CUENCA, João Paulo. O dia Mastroianni, 2007, p. 39.

28. Ibidem, p. 61-62.
- NÃO TENHO TEMPO PARA AS SUAS BANALIDADES METAFÍSICAS. CONTE-ME SOBRE A MINHA VIDA! FALE SOBRE MIM AGORA.

- Não o conheço. Você deve ser uma figura inventada.

- MAS VOCÊ ME CHAMOU AQUI. PARA QUE EU APRENDESSE MAIS SOBRE MIM MESMO. [grifos nossos $]^{27}$.

Nas passagens destacadas, o protagonista inverte o sentido ficcional: a figura "inventada" é a Voz, que pode representar tanto o leitor quanto o escritor, que "nascem" - ou nos termos da passagem, são "chamados" - no momento da leitura e da criação, respectivamente. O escritor, longe de ser um demiurgo, "nasce" juntamente com suas personagens, o processo de engendramento é mútuo e especular, à semelhança do "nascimento" do leitor. A feição metacrítica, no entanto, fica mais evidente em outro momento, quando o embate verbal entre Cassavas e a Voz versa, previsivelmente, sobre a problemática da relevância/permanência/transformação da literatura na contemporaneidade. Entre as fragilidades da vertente denominada pós-moderna da literatura contemporânea, a Voz aponta, por exemplo, o uso exaustivo de recursos metalinguísticos, o cinismo, a alienação, o sarcasmo e a própria autorreflexividade:

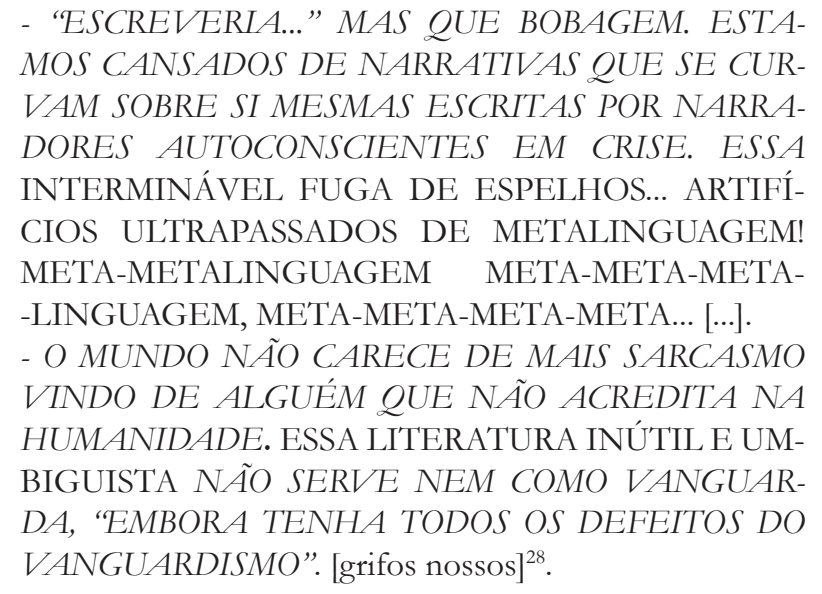

No fragmento, a faceta metacrítica encontra a perspectiva autoirônica frente ao literário e o alvo de críticas é a autorreflexividade, tornada hoje, um lugar comum. As próprias epígrafes do romance - que remetem à masturbação - já direcionam ao referido intento crítico, se considerarmos o fato de que a literatura "umbiguista" parece, inicialmente, um ato de autossatisfação:

O verdadeiro herói é o que se diverte sozinho.

Charles Baudelaire

Eu fui o maior onanista de meu tempo.

Oswald de Andrade 
No romance, porém, a criticidade não se limita às reiterações pós-modernas, estendendo-se ao próprio - e talvez ultrapassado - questionamento sobre a necessidade de afirmação de uma identidade brasileira. Entre as indagações da Voz dirigidas a Cassavas estão perguntas do tipo "POR QUE NÃO [ouve] UM CHORINHO? OU UM LUNDU HONRANDO SUAS ORIGENS AFRICANAS?"; e advertências como "E BRASILEIRO BEBE CACHAÇA, NÃO BEBE MARTINI OU FERNET. NO MÁXIMO STEINHAGEN"29. Tanto o questionamento quanto a exortação expostos são claramente irônicos, se pensarmos o romance em análise como um produto contemporâneo, período no qual as fronteiras culturais são constantemente atravessadas e/ou rasuradas, o que torna a afirmação de uma (suposta) identidade nacional coesa um anacronismo.

Há outras passagens do romance que ironizam a "irrelevância" da literatura na contemporaneidade, como o momento no qual Cassavas, ao atravessar o camelódromo na companhia de Tomás Anselmo, percebe uma ausência: "Procuro pelo velho que vendia livros. Mudou de ponto, morreu, pouco se sabe: não há mais livros na calçada. Não teria outros compradores? Quem quer saber de livros, afinal?" 30 . A ironia do personagem também se acentua quando, ao topar com um pedinte, questiona se o mesmo seria um bardo: "O pobre materialista se aproxima e nos pede dinheiro. Seria um bardo? Respondo à palma da mão imunda: - Desculpe meu amigo, hoje não estou pra poesia"31. O sarcasmo e o desdém que atravessam o discurso do personagem - aqui, voltados tanto à literatura quanto às urgências sociais que têm as grandes cidades como palco -, no entanto, parecem também produtos de vitrine, se os considerarmos como construtos forçosamente cínicos e obrigatoriamente superficiais, nos quais é possível entrever a angústia, a melancolia diante da indiferença dispensada ao literário. A indiferença voltada à situação do pedinte também parece performática e autoirônica, uma espécie de mea culpa do escritor, cujo romance está voltado mais para questões estético/estilísticas (e mesmo ensaísticas) do que sociais. Ao final do romance, surge o narrador em terceira pessoa, que conta ao leitor uma outra travessia do personagem, dessa vez, rumo ao vazio (ou ainda, à latência):

À medida que Cassavas caminha pelas ruas amareladas da cidade a amanhecer preguiçosa, suas galerias, estufas de vidro, salões espalhados, balcões de mármore, praças dormentes, teatros, domos e postes recém-apagados explodem por trás dos passos do nosso herói. E suas colinas, ladeiras, arcos, escadarias, cassinos, hotéis, veleiros, mesquitas, praias e restaurantes giratórios são sugados pelo vazio. [...]. E as fotos desbotadas e os papéis em branco dentro das gavetas. E suas linhas de trem, longos corredores, livrarias ovais e balaustradas de mármore sobre escadarias em espiral. E também
29. Ibidem, p. 111.

30. Ibidem, p. 32.

31. Ibidem, p. 31-32. 

passadas e futuras, e todos os que os conhecerem e fossem por eles lembrados [...].

Quando terminarmos de ler e contar a história desse personagem, também desapareceremos.

Até o dia em que Pedro Cassavas volte a olhar para algum de nós. [grifos nossos] $]^{32}$

As passagens em destaque direcionam à questão metacrítica, uma vez que a dinâmica da leitura (literária) e dos sujeitos por ela envolvidos vêm à tona. Leitor, narrador e personagens, seres que só existem durante a leitura, têm as suas vidas limitadas pela última página. No entanto, a dinâmica da leitura, segundo o narrador, pode sempre recomeçar, mas em ordem inversa, quando Pedro Cassavas (protagonista) "olhar" para um de nós (leitores, o próprio escritor enquanto leitor). O olhar do personagem voltado para um "nós" se materializa sempre que a sua forma ressurgir em nosso imaginário - o último, alegorizado na passagem pelo turbilhão de imagens "sugadas" pelo vazio -, o que pode levar a um novo encontro, a uma nova leitura. Se o protagonista, por sua vez, nos "olha" é porque ele está, simultaneamente, dentro e fora do livro, assim como "nós", leitores. A ligação entre "ele" e "nós" remete a uma espécie de equivalência ou de espelhamento, cuja mediação não se dá propriamente por um "espelho", mas por uma "vitrine", que reflete imagens fragmentadas, voláteis e, por isso mesmo, consumíveis. Sob a aparente superficialidade da ficção de vitrine, porém, a releitura pode encontrar uma profundidade imprevista, uma incitação a uma espécie de autoria por parte do leitor, impulsionado a descobrir novos minissimbolos, a decodificar facilmente as infinitas minúcias que distinguem reiterações à superfície.

Taxar a literatura autorreflexiva como superficial parece um argumento demasiado simplista, à semelhança do que ocorreu nos primórdios da crítica cinematográfica e televisiva. Concisão, agilidade e repetições temático-estilísticas não são apenas modos de cooptação e atestados de previsibilidade, mas estratégias inicialmente "sedutoras" que desafiam o receptor/leitor a buscar unicidades nas (aparentes) repetições.

\section{Referências}

BARTHES, Roland. O rumor da lingua. São Paulo: Brasiliense, 1988.

BUSATO, Susana. "A consciência do zero como a lógica da razão antropofágica da poesia brasileira contemporânea". In: 
MOTTA, Sérgio Vicente; BUSATO, Susana (orgs.). Figurações contemporâneas do espaço na literatura. São Paulo: Editora UNESP; Cultura Acadêmica, 2010, p. 11-26.

CANEVACCI, Massimo. A antropologia da comunicação visual. Rio de Janeiro: DP\&A, 2001.

CUENCA, João Paulo. O dia Mastroianni. Rio de Janeiro: Agir, 2007.

KLINGER, Diana. Escritas de si, escritas do outro: o retorno do autor e a virada etnográfica. Rio de Janeiro: 7 Letras, 2012.

OLIVEIRA, Fabiano. "Conhecendo o simulacro". Caligrama, [S.1.], v. 1, n. 1, abr. 2005. Disponível em: < http://www. revistas.usp.br/caligrama/article/viewFile/61336/64276>. Acesso em: 21 jul. 2015.

PIGLIA, Ricardo. "O escritor enquanto crítico". Revista Travessia, Florianópolis, UFSC, n. 33, 1996.

RESENDE, Beatriz. Contemporâneos: expressões da literatura brasileira no século XXI. Rio de Janeiro: Casa da Palavra, 2008.

STAM, Robert. Introdução à teoria do cinema. Campinas: Papirus, 2003.

SÜSSEKIND, Flora. Papéis colados. Rio de Janeiro: UFRJ, 2003.

VILLAÇA, Nízia. Mixologias. São Paulo: Estação das Letras e Cores, 2010. 
